\title{
Pengaruh Penggunaan Poster Sebagai Media Pengingat terhadap Kepatuhan Kebersihan Tangan Perawat Pelaksana di Rumah Sakit Penyakit Infeksi (RSPI) Prof. Dr. Sulianti Saroso
}

\author{
Influence of Role Posters on Hand Hygiene of Nurses in Infectious Disease \\ Hospital Prof. Dr. Sulianti saroso
}

\author{
Anitha ${ }^{1 *}$, Hanny Handiyani ${ }^{2}$, Sukihananto ${ }^{3}$ \\ ${ }^{1}$ RSPI Prof. Dr. Sulianti Saroso \\ 2Departemen Keperawatan Dasar Fakultas IImu Keperawatan Universitas Indonesia. \\ ${ }^{3}$ Departemen Keperawatan Komunitas Fakultas IImu Keperawatan Universitas \\ Indonesia
}

*Korespondensi Penulis :

Anitha

Email: nitasupriono@yahoo.com

\begin{abstract}
Abstrak
Latar belakang : Kebersihan tangan merupakan tindakan yang paling efektif dalam mencegah penularan agen patogen saat memberikan pelayanan kesehatan, namun tingkat kepatuhan kebersihan tangan perawat masih rendah. WHO meluncurkan strategi multimodal dengan salah satu strateginya adalah strategi pengingat. Tujuan penelitian ini adalah untuk mengidentifikasi pengaruh poster sebagai media pengingat terhadap kepatuhan kebersihan tangan perawat pelaksana di RSPI Prof. Dr. Sulianti Saroso.

Metode : Desain penelitian kuantitatif dengan menggunakan metode pre eksperimen secara perlakuan ulang (one group pre and post test design). Sampel 34 perawat diambil menggunakan teknik purposive sampling. Analisis data menggunakan uji Wilcoxon, uji Spearman, dan uji T-Independent.

Hasil : Kepatuhan kebersihan tangan sebelum dilakukan intervensi sebesar 34,3\% dan setelah dilakukan intervensi $47,14 \%$. Ada perbedaan yang bermakna terhadap kepatuhan kebersihan tangan perawat pelaksana sebelum dan setelah dilakukan intervensi (Pvalue $=0,001 ; \mathrm{Cl} 95 \%=43.3 \% ; 51.73 \%$ ). Hasil analisis didapatkan tidak ada hubungan yang bermakna antara usia ( $P$ value $=0,811)$, masa kerja ( $P$ value $=0,673)$ dan jenis kelamin $(P$ value $=0,376)$ dengan kepatuhan kebersihan tangan setelah intervensi. Ada hubungan tingkat pendidikan dengan kepatuhan kebersihan tangan setelah intervensi $(P v a l u e=0,031$; $95 \% \mathrm{Cl}=-1,46 ;-28,18)$.

Kesimpulan : Ada perbedaan yang bermakna terhadap kepatuhan kebersihan tangan perawat pelaksana di RSPI Prof. Dr. Sulianti Saroso sebelum dan setelah dilakukan intervensi.
\end{abstract}

Kata kunci: Kebersihan tangan, kepatuhan perawat, poster

\begin{abstract}
Background : Hand hygiene is the most effective measure to prevent pathogen transmission during health-care delivery, but compliance of nurses in performing hand hygiene is usually low. WHO developed a multimodal strategies for increasing a compliance in hand hygiene and one of them is reminder strategy. This study aims to identify the influence of posters as reminders to nurses hand hygiene performance compliance at Infectious Disease Hospital Prof. dr. Sulianti Saroso.

Methods : Quantitative research design with pre experiments method using one group pre and post test. Sample are 34 nurses and purposive sampling technique was used. Wilcoxon test, independent $t$ test, and Spearman test was used for data analys.
\end{abstract}


Results : Hand hygiene compliance before the intervention of $34.3 \%$ and $47.14 \%$ after intervention. There is a significant difference in hand hygiene compliance of nurses before and after the intervention (Pvalue = $0.001 ; 95 \% \mathrm{Cl}=43.3 \% ; 51.73 \%)$. The results of the analysis we found no significant relationship between age $(P$ value $=0.811)$, tenure ( $p$ value $=0.673)$ and gender (Pvalue $=0.376)$ with hand hygiene compliance after the intervention. There is a relationship with the educational level of hand hygiene compliance after the intervention (Pvalue $=0.031 ; 95 \% \mathrm{Cl}=-1.46 ;-28.18$ ).

Conclusion : There is a significant differences compliance of hand hygiene of nurses at infectious disease hospital Prof. Dr. Sulianti Saroso before and after the intervention.

Keywords: Hand hygiene, nurse compliance, poster

\section{Pendahuluan}

Kebersihan tangan merupakan tindakan yang paling efektif dalam mencegah penularan agen patogen saat memberikan pelayanan kesehatan, namun tingkat kepatuhan dalam melakukan kebersihan tangan dinilai masih belum memberikan hasil yang baik. Penelitian sebelumnya menunjukkan bahwa sangat penting melakukan kebersihan tangan yang baik guna mencegah penyakit dan infeksi, namun tingkat kepatuhan melakukan kebersihan tangan tetap rendah di antara petugas kesehatan. Data statistik nasional mengenai tingkat kepatuhan kebersihan tangan petugas kesehatan yang didapatkan di 656 rumah sakit umum dan swasta di Australia pada Oktober 2012 adalah sebesar 76,4\%. Data yang didapatkan dari laporan Infection Prevention Control Nurse (IPCN) tahun 2014 sebanyak 40,29\% petugas kesehatan tidak melakukan kebersihan tangan sebelum kontak dengan pasien dan 3,4\% tidak melakukan kebersihan tangan setelah kontak dengan pasien. ${ }^{1,2}$
Manager mempunyai peranan yang sangat penting di dalam meningkatkan kepatuhan perawat melakukan kebersihan tangan. Memotivasi serta memberikan bimbingan dan arahan kepada perawat merupakan peran dari manager keperawatan. Banyak strategi yang telah digunakan untuk meningkatkan kepatuhan kebersihan tangan. WHO pada tahun 2009 meluncurkan lima strategi multimodal. Memberikan pengingat di tempat kerja merupakan alat kunci untuk mendorong dan mengingatkan petugas kesehatan tentang pentingnya kebersihan tangan serta indikasi yang tepat dalam melakukan kebersihan tangan (21-30). Pengingat yang digunakan untuk meningkatkan kepatuhan kebersihan tangan dapat berupa poster, leaflet dan screensaver. Pemilihan poster digunakan karena poster mempunyai kelebihan dibandingkan dengan media visual lainnya. ${ }^{2,3,4}$

Penelitian yang dilakukan oleh Filion, et all menyatakan bahwa penggunaan poster dan ketersediaan 
alat yang mudah diakses dapat meningkatkan kepatuhan kebersihan tangan secara menyeluruh di kantin rumah sakit Amerika. Menempel poster di dekat tempat penggunaan alat kebersihan tangan adalah salah satu cara memberikan isyarat untuk bertindak, walaupun kecil tetapi memiliki efek berkelanjutan pada kebersihan tangan. ${ }^{5,6}$

Penelitian tentang pengaruh penggunaan poster sebagai media pengingat terhadap kepatuhan kebersihan tangan belum banyak dilakukan sehingga penulis tertarik untuk melakukan penelitian ini.

\section{Metode}

Penelitian ini merupakan penelitian kuantitatif dengan metode pre eksperimen menggunakan one group pre and post test design. Sampel sebanyak 34 perawat pelaksana yang ada di delapan ruang perawatan termasuk ICU di ambil dengan cara purposive sampling. Pengumpulan data menggunakan metode observasi langsung yang dilakukan oleh delapan petugas infection prevention control nurse (IPCLN) dengan menggunakan formulir observasi yang telah dimodifikasi dari WHO Sebelum melakukan observasi Uji inter-rater reliability terlebih dahulu dilakukan dan didapatkan nilai Kappa > 0,60 sehingga peneliti menyimpulkan tidak ada perbedaan persepsi antara peneliti dan observer. Data diolah dan dianalisis menggunakan analisis univariat, bivariat ,independent t test, Spearman test dan Wilcoxon test.

Observasi dilakukan sebanyak 20 kali kesempatan, satu kali pengamatan akan di observasi selama 10 menit, meliputi five moment dan langkahlangkah melakukan kebersihan tangan dapat berupa handrub berbasis alkohol atau menggunakan air mengalir dan sabun sesuai dengan standar WHO. Bila salah satu langkah terlewatkan ataupun tidak sesuai dengan urutan maka kebersihan tangan dianggap tidak benar. Poster langkah-langkah kebersihan tangan ditempelkan di dekat wastafel, didekat penempatan handrub, empat poster kebersihan tangan ditempelkan di koridor ruang perawatan, tiga poster di tempatkan di nurse station dan satu poster ditempelkan di setiap pintu kamar pasien. Penelitian ini telah mendapatkan keterangan exempted dari Komite Etik Rumah Sakit Penyakit Infeksi Prof. Dr. Sulianti Saroso Jakarta.

\section{Hasil}

Hasil analisis dari penelitian ini menunjukkan rata-rata usia perawat pelaksana adalah 32,12 tahun dengan standar deviasi 3,79 tahun $(95 \% \mathrm{Cl}=$ $30,79 ; 33,44)$. Umur rerata perawat 
pelaksana di RSPI Prof. Dr. Sulianti Saroso berada dalam rentang umur produktif. Rerata masa kerja perawat enam tahun dengan masa kerja tersingkat satu tahun dan terlama 18 tahun $(95 \%: \mathrm{Cl}=5,15 ; 7,31)$. Hasil analisis terhadap jenis kelamin relatif homogen dengan mayoritas perawat pelaksana adalah perempuan $(91,2 \%)$. Tingkat pendidikan D3 Keperawatan lebih banyak $(67,6 \%)$ dan sebagian besar perawat pelaksana telah mengikuti pelatihan kebersihan tangan (100\%).

Hasil analisis menunjukkan rerata kepatuhan kebersihan tangan sebelum dilakukan intervensi sebesar 34,3\% dengan nilai kepatuhan terkecil adalah sebesar 23,57 \% dan terbesar adalah $94,24 \%(\mathrm{Cl} 95 \%=35,83 ; 50,77)$ dan setelah dilakukan intervensi dengan rerata $47,14 \%$ dengan nilai kepatuhan terkecil adalah sebesar $25,50 \%$ dan terbesar adalah 95,71\% (Cl 95\%= 45,11; 58,35). Uji yang dilakukan didalam menganalisis penelitian ini adalah menggunakan uji Wilcoxon dan didapatkan hasil terdapat perbedaan yang bermakna terhadap kepatuhan kebersihan tangan perawat pelaksana di RSPI Prof. Dr. Sulianti Saroso sebelum dan setelah dilakukan intervensi
(Pvalue=0,001; Cl 95\%=43.3\% ;51.73\%) terlihat pada tabel 1.

Nilai kepatuhan kebersihan tangan setelah dilakukan intervensi berdasarkan five moment yang tertinggi berada pada moment setelah kontak dengan pasien sebesar $63,82 \%$ dan terendah pada moment setelah kontak dengan cairan tubuh 11,62\% (Gambar 1).

Pelaksanaan observasi perilaku kepatuhan kebersihan tangan yang di laksanakan sebanyak 20 kali kesempatan setelah dilakukan intervensi didapatkan perilaku kepatuhan kebersihan tangan mulai naik pada pengamatan ke-12 dan tertinggi berada pada pengamatan ke-15 (Gambar 2).

Hubungan karakteristik perawat menurut usia dan masa kerja dengan kepatuhan kebersihan tangan setelah dilakukan intervensi dilakukan dengan menggunakan uji Sperman. Hasil analisis didapatkan tidak ada hubungan yang bermakna antara usia dengan kepatuhan kebersihan tangan $(p=0,811)$ setelah intervensi. dan tidak ada hubungan yang bermakna antara karakteristik masa kerja dengan kepatuhan kebersihan tangan setelah intervensi $p=0,673$ ). Hasil analisis disajikan pada tabel 2. 
Tabel 1. Pengaruh Poster Sebagai Media Pengingat terhadap Kepatuhan Kebersihan Tangan Perawat Pelaksana di RSPI Prof. Dr. Sulianti Saroso Tahun 2015

\begin{tabular}{ccccc}
\hline Kepatuhan & Median & Rerata \pm SD & Min-Maks & $P$ \\
\hline Sebelum & 34,3 & $43,3 \pm 21,40$ & $23,57-94,29$ & 0,001 \\
Sesudah & 47,14 & $51,73 \pm 18.9$ & $25,50-95,71$ & \\
\hline
\end{tabular}

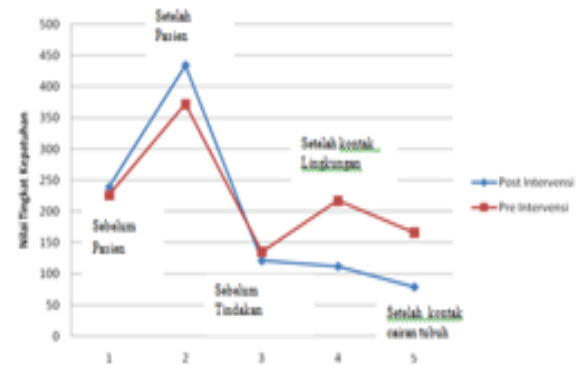

Gambar 1. Distribusi Kepatuhan Kebersihan Tangan Perawat Pelaksana Berdasarkan Five Moment Sebelum dan Setelah Intervensi

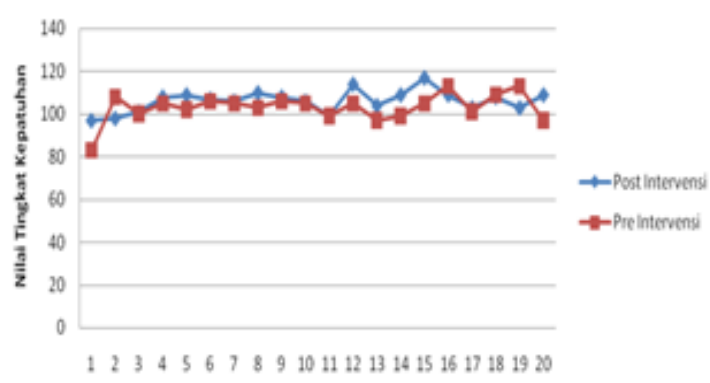

Gambar 2. Distribusi Perilaku Kepatuhan Kebersihan Tangan Perawat Pelaksana Sebelum dan Setelah Intervensi

Tabel 2. Hubungan Usia dan Masa Kerja dengan Kepatuhan Kebersihan Tangan Perawat Pelaksana di RSPI Prof Dr. Sulianti Saroso Tahun 2015

\begin{tabular}{ccc}
\hline \multirow{2}{*}{ Variabel } & \multicolumn{2}{c}{ Kepatuhan kebersihan tangan setelah intervensi } \\
\cline { 2 - 3 } & $\mathrm{r}$ & $p$ \\
\hline Usia & 0,043 & 0,811 \\
Masa Kerja & 0,075 & 0,673 \\
\hline
\end{tabular}

Hasil analisis tingkat pendidikan perawat pelaksana menunjukkan bahwa terdapat perbedaan yang bermakna antara kepatuhan kebersihan tangan perawat pelaksana tingkat pendidikan S1 dengan tingkat pendidikan D3 yang ada di rumah sakit tersebut setelah diberikan intervensi. (Pvalue $=0,031$;
$95 \% \mathrm{Cl}=-1,46 ;-28,18)$. Sedangkan hasil analisis jenis kelamin menunjukkan tidak terdapat perbedaan yang bermakna antara jenis kelamin dengan kepaatuhan kebersihan tangan perawat pelaksana (Pvalue $=0,376 ; 95 \mathrm{Cl}=-13,10 ; 33,76)$. Hasil analisis disajikan pada tabel 4. 
Tabel 4. Hubungan Tingkat Pendidikan dan Jenis Kelamin dengan Kepatuhan Kebersihan Tangan Perawat Pelaksana di RSPI Prof Dr. Sulianti Saroso Tahun 2015

\begin{tabular}{|c|c|c|c|c|c|}
\hline \multirow{2}{*}{ Variabel } & \multicolumn{5}{|c|}{ Kepatuhan Kebersihan Tangan Setelah Intervensi } \\
\hline & $\mathrm{n}$ & Rerata & Median & PValue & $95 \% \mathrm{Cl}$ \\
\hline Tingkat pendidikan & & & $-14,82$ & 0,031 & $-28,18 ;-1,46$ \\
\hline D3 Kep & 23 & $46,93(16,71)$ & & & \\
\hline S1 Kep & 11 & $61,75(20,24)$ & & & \\
\hline Jenis Kelamian & & & $-10,33$ & 0,376 & 33,$76 ;-13,10$ \\
\hline Laki-laki & 3 & $42,31(17,27)$ & & & \\
\hline Perempuan & 31 & $52,64(19,14)$ & & & \\
\hline
\end{tabular}

\section{Pembahasan}

Usia ini merupakan periode masa seseorang memiliki kematangan baik secara fisik maupun secara psikologis. Robbins menyatakan bahwa usia 20-40 tahun merupakan tahap perkembangan dewasa muda dan pada tahap ini merupakan tahap perkembangan puncak dari kondisi fisik seseorang dalam mengaplikasikan ilmu pengetahuan dan keterampilan yang dimilikinya. $^{7}$

Hasil penelitian diketahui usia tidak mempengaruhi kepatuhan kebersihan tangan perawat pelaksana karena ada beberapa faktor lain yang meningkatkan kepatuhan kebersihan tangan misalnya pola komunikasi, keyakinan/nilai-nilai yang diterima perawat,serta dukungan sosial dan pengetahuan tentang pentingnya kebersihan tangan. Sejalan dengan pernyataan Efstathiou, et all menyatakan bahwa kepatuhan dapat dipengaruhi oleh beberapa faktor seperti budaya, sosial ekonomi, pengetahuan dan sarana prasarana. Walaupun di rentang usia 20-40 tahun seseorang telah memiliki kematangan dalam berprilaku dan berketerampilan dengan baik. ${ }^{8}$

Hasil penelitian berdasarkan jenis kelamin menunjukkan sebagian besar perawat pelaksana yang ada adalah perempuan, hal ini sejalan dengan pendapat yang dikemukakan oleh Walker yang menyatakan bahwa profesi keperawatan dikenal sebagai profesi perempuan Wade dan Travis juga menyatakan alasan perempuan lebih banyak menjadi perawat dibandingkan dengan laki-laki karena perawat perempuan lebih peka dibandingkan dengan perawat laki-laki. ${ }^{1,9}$

Hasil analisis penelitian ini menunjukkan tidak terdapat perbedaan yang bermakna antara jenis kelamin laki-laki dan perempuan dengan tingkat kepatuhan kebersihan tangan perawat yang ada di RSPI Prof. Dr. Sulianti 
Saroso. Sejalan dengan hasil penelitian yang dilakukan oleh Tumkaya menyatakan bahwa tidak ada perbedaan dalam proses pembelajaran dari pria dan wanita yang berpengaruh terhadap perilakunya. $^{10}$ Hal ini tidak sejalan dengan pendapat yang dikemukakan oleh Gibson, Ivasncevich, dan Donnelly yang menyatakan bahwa laki-laki dan perempuan mempunyai kemampuan dan kecerdasan yang sama dalam hal belajar, daya ingat, kemampuan bernalar, dan kreativitas. ${ }^{11}$

Hasil penelitian didapatkan perawat dengan tingkat pendidikan D3 keperawatan lebih dominan dibandingkan dengan yang berpendidikan sarjana sehingga bisa dikatakan bahwa perawat pelaksana yang ada di rumah sakit tersebut masih berpendidikan vokasional dan hanya sebagian kecil yang spesialis (Ners). Hal ini sejalan dengan data yang didapatkan dari BPSDM-KEMENKES yang menyatakan bahwa tenaga perawat yang ada di Indonesia sebagian besar memiliki tingkat pendidikan D3 keperawatan. ${ }^{4} \quad$ Penelitian lain menyatakan bahwa tingkat pendidikan diploma tiga merupakan tingkat pendidikan untuk professional pemula perawat, tingkat pendidikan professional perawat adalah minimal tingkat sarjana, sehingga diasumsikan bahwa perawat dengan tingkat pendidikan yang lebih tinggi dapat memberikan perawatan secara profesional karena memiliki pengetahuan dan sikap yang lebih baik. Selain itu ditambahkan dari penelitian sebelumnya menyatakan bahwa tingkat pendidikan dapat digunakan sebagai landasan untuk meningkatkan pengetahuan dan pemahaman seseorang akan perilaku kepatuhan ${ }^{12,13,14}$

Tingkat pendidikan yang cukup tinggi, keterampilan dan pengetahuan perawat juga akan bertambah. Hal tersebut dapat dilihat dari hasil penelitian ini bahwa perawat yang mempunyai tingkat pendidikan lebih tinggi di ruangan lebih patuh didalam melakukan kebersihan tangan.

Masa kerja sangat berpengaruh terhadap produktifitas kerja dari seseorang. Semakin lama seseorang bekerja, semakin banyak pula pengalaman kerja yang nantinya akan meningkatkan produktifitas dari orang tersebut. $4,7,14$

Hasil analisis masa kerja dari perawat pelaksana didapatkan masa kerja tersingkat adalah satu tahun dan terlama adalah 18 tahun dengan tidak didapatkan hubungan yang bermakna antara masa kerja dengan kepatuhan kebersihan tangan perawat pelaksana setelah diberikan intervensi. Hal ini tidak sejalan dengan penelitian yang dilakukan oleh Saragih dan Natalina 
yang menyatakan ada hubungan yang bermakna antara lama bekerja dengan tingkat kepatuhan kebersihan tangan di rumah sakit Columbia Asia Medan. ${ }^{15}$

Kepatuhan kebersihan tangan merupakan salah satu faktor yang sangat menentukan didalam memutus dan mencegah terjadinya HAls. Cara yang dilakukan untuk memutus rantai infeksi adalah dengan melakukan kebersihan tangan. Meskipun sangat penting melakukan kebersihan tangan yang baik guna mencegah HAls, namun tingkat kepatuhan kebersihan tangan masih rendah diantara petugas kesehatan. ${ }^{16}$ Banyak strategi yang telah digunakan.untuk mengatasi hal tersebut. WHO membuat strategi multimodal dan salah satunya dengan menggunakan strategi pengingat yaitu poster. Pengukuran kepatuhan kebersihan tangan setelah intervensi dilakukan dua minggu setelah penempelan poster dan dari hasil analisis penelitian ini menunujukkan bahwa kepatuhan kebersihan tangan setelah dilakukan pemasangan poster adalah 47,14\% dan terdapat peningkatan kepatuhan kebersihan tangan sebesar $12,84 \%$.

Hasil observasi yang didapatkan peneliti terkait kelengkapan fasilitas hand hygiene dimasing-masing ruangan dilengkapi dengan wastafel, air bersih yang mengalir lancar, sabun cair antiseptic, tissue sekali pakai, dan handrub berbasis alcohol yang terpasang di samping pintu masuk kamar pasien merupakan faktor yang mendukung di dalam peningkatan kepatuhan kebersihan tangan perawat.

Hal ini sejalan dengan penelitian yang dilakukan oleh Fillion et all. meyatakan bahwa penggunaan poster dan ketersediaan alat yang mudah diakses dapat meningkatkan kepatuhan kebersihan tangan secara menyeluruh di kantin rumah sakit Amerika.(11) Begitupula penelitan yang dilakukan oleh Huang \& Wu yang menunjukkan bahwa adanya signifikan pengaruh program pelatihan komprehensif kebersihan tangan terhadap pengetahuan dan kepatuhan nurse assistants. ${ }^{17}$

Hasil penelitian juga didapatkan tingkat kepatuhan kebersihan tangan berdasarkan five moment setelah dilakukan intervensi didapatkan kepatuhan tertinggi ditemukan pada saat setelah kontak dengan pasien $(63,82 \%)$, sedangkan kepatuhan terendah adalah setelah kontak dengan cairan tubuh $(11,62 \%)$. Hal ini terjadi karena perawat yang ada di ruangan masih sering dan terbiasa menggunakan sarung tangan pada saat melakukan tindakan keperawatan.Tenorio et all mengatakan walaupun penggunaan sarung tangan telah terbukti keefektifannya di dalam 
mencegah kontaminasi yang berasal dari petugas kesehatan, namun penggunaan sarung tangan tidak menggantikan kebersihan tangan Petugas kesehatan khususnya perawat harus dapat menilai kapan dan waktu yang tepat untuk menggunakan sarung tangan. ${ }^{18}$

\section{Kesimpulan}

Gambaran kepatuhan kebersihan tangan perawat pelaksana sebelum dan setelah intervensi didapatkan peningkatan kepatuhan kebersihan tangan. Ada perbedaan kepatuhan yang bermakna antara sebelum dan setelah dilakukan intervensi di ruang perawatan. Karakteristik demografi individu salah satunya tingkat pendidikan perawat pelaksana didapatkan berhubungan secara bermakna dengan kepatuhan kebersihan tangan setelah dilakukan intervensi.

\section{Ucapan Terima Kasih}

Penulis ucapkan terima kasih kepada institusi RSPI Prof. Dr. Sulianti Saroso dan semua pihak yang terlibat dalam proses pengumpulan dan analisa data.

\section{Daftar Pustaka}

1. Wilson, S., Jacob, C. J., \& Powell, D. Behavior-change interventions to improve hand-hygiene practice: A review of alternatives to education.
Critical Public Health. 2011 21(1), 119-127.

doi:10.1080/09581591009786122.

2. World Health Organization. WHO quidelines on hand hygiene in health care: first global patient safety challenge clean care is safer care. 2009 Retrieved from http://whqlibdoc.who.int/publications/2 009/9789241597906_eng.pdf

3. Marquis, B.L \& Huston, C.J Kepemimpinan dan manajemen keperawatan: Teori \& Aplikasi. (Widyawati, Penerjemah) 4th ed. Philadelphia: Lippincott. 2010.

4. Pittet, D., Allegranzi, B., Saz, H., Dharan, S., Pessoa-Silva, C.L., Donaldson, L., Boyce, J.M. WHO Global Patient Safety Challenge, World Alliance for Patient Safety. The Lancet infectious diseases, 2006. 6(10), 641-652.Retrived from http://www.ncbi.nlm.nih.gov/pubmed/ 20004812

5. Filion, K., KuKanich, K.S., Chapman, B., Hardigree, M.K., \& Powell, D.A. Observation-based evaluation of hand hygiene practices and the effects of an intervention at a public hospital cafeteria. American Journal of Infection Control, 2011. 39(6), 464470. http://dx.doi.org/10.1016/j.ajic. 2010.09.016.

6. John A., Amber.S., Emanuel., Kristel M., Gallagher \& Christopher T., SteinmanKent State Universityrief Report: Framing flu prevention - an experimental field test of signs promoting hand hygiene During the 2009-2010 H1N1 Pandemic. Retrived from

http://updegrafflab.org/files/4313/388 6/8291/UpdegraffEmanuelGallagherS teinman-HealthPsychology.pdf

7. Robbins, S. P, Organizational behavior: Concepts controversies 
applications, $8^{\text {th }}$ ed. New Jersey: Pretince Hall Inc. 2008.

8. Efstathiou, G., Papastavrou, G., Raftopoulous, V., Merkouris, A. Factors influencing nurses compliance with standard precautions in order to avoid occupational exposure to microorganisms: A focus group study. BMC Nursing. 2014. 10(1),

1.http://www.biomedcentral.com/1472 $-6955 / 10 / 1$

9. Wade, C. D. \& Travis, C. Psikologi. Jakarta: Erlangga; 2007.

10. Swansburg, R., C. Management and leadership for nurse manager. United States of America: Jones and Bartlett. 2002

11. Gibson, J.L., Ivancevich, J.M., Donnelly, Jr., J.H., Organisasi: Perilaku, Struktur, Proses (Terj.), Penerbit Erlangga, Jakarta.1997

12. BPPSDM-KEMENKES. mendominasi tenaga

Perawat 2011 Diunduh dari http://www. bppsdmk.depkes.go.id.

13. Centers for Disease Control and Prevention. Handwashing: Hand hygiene saves lives, 2009 Dec 7. (cited 2010 Jun 30) Available from: URL: http://www.cdc.gov/cleanhands/

14. Roberts, S. A., Sieczkowski, C.,Campbell, T., Balla, G., \& Groups,
W.. Implementing and sustaining a hand hygiene culture change programme at Auckland District Health Board. The New Zealand Medical Journal, 2012. 125(13540, 75-85. Diunduh dari http://search.proquest.com/docview/1 034429973/accountid $=17242$

15. Saragih, R.. \& Natalina, R.. Hubungan karakteristik perawat dengan tingkat kepatuhan perawat melakukan cuci tangan di Rumah Sakit Columbia Asia Medan. Jurnal IImu Keperawatan, 2011 3(1). Diunduh dari http://uda.ac.id/ jurnal/files/7.pdf

16. Tumkaya, S. The Investigation of the epistemological beliefs of university students according to gender, grade, fields of study, academic success and their learning styles. Educational Sciences: Theory \& Practice, 12(10, 88-95. 2012. Diunduh dari http://www.edam.com.tr/estp.

17. Huang \& Wu. Evaluation of a training programme on knowladge and compliance of nurse assistants hand hygiene in nursing homes. Journal of Hospital Infection; 68 . 2008.(164-70). Diunduh dari http://www.thecochranelibrary.com

18. Taylor, C. R. \& LeMone, P. Fundamentals of nursing: The art and science of nursing care. $7^{\text {th }} \mathrm{Ed}$. Philadhelpia: Lippincott Williams \& Wilkins.2010 